\title{
Determination and Analysis of Valsartan by Spectrophotometry
}

\author{
Sandeg Bhyarani \\ Department of BS\&H Avanthi institute of Engineering and Technology, Vizianagaram 531162, India
}

\begin{abstract}
A simple, sensitive and cost effective visible spectrophotometric method has been developed for the determination of Valsartan from bulk and tablet dosage forms. The method is based on the formation of green colored coordination complex by the drug with cobalt thiocyanate which is quantitatively extractable into nitro benzene with an absorption maximum of 605nm. The Regression analysis of Beer's Law plot showed good correlation in a general concentration range of $0.5-3.0 \mathrm{ml}, 400 \mu \mathrm{g} / \mathrm{ml}$ with correlation coefficient $(r=0.992)$. The proposed method is validated with respect to accuracy, precision, linearity and limit of detection. The suggested procedure is successfully applied to the determination of the drug in pharmaceutical preparation, with high percentage of recovery, good accuracy and precision. The results of analysis have been validated statistically by repeatability and recovery studies. The results are found satisfactory and reproducible. The method is applied successfully for the estimation Valsartan in tablet form without the interference of excipients.
\end{abstract}

Keywords: Beer's Law, Cobalt thiocyanate, Extractive Spectrophotometry, Nitrobenzene, Valsartan

\section{Introduction}

Valsartan is an Angiotensin Receptor Blocker (ARB) that shows high affinity for theangiotensin II type 1 (AT1) receptors, has a long duration of action, and has the longest half - life of any ARB It is an angiotensin II receptor antagonist, effective in the treatment of hypertension It is also effective when used alone or in combination with other drugs for the treatment of high blood pressure.

Diovan (Valsartan) is a nonpeptide, orally active, and specific angiotensin II receptor blocker acting on the AT1 receptor subtype. Valsartan is a white to practically white fine powder. It is soluble in ethanol and methanol and slightly soluble in water. Angiotensin II Receptor type 1 antagonists have been widely used in treatment of diseases like hypertension, heart failure, myocardial infarction and diabetic nephropathy. Their beneficial effects are related to inhibition of Angiotensin II by blockade of AT1 receptor. It was first developed by Novartis and has a wide market in the developed and the developing countries Valsartan is an angiotensin II receptor blocker (ARB). It works by blocking a substance in the body that causes the blood vessels to tighten. Valsartan relaxes the blood vessels and lowers blood pressure. A lower blood pressure will increase the supply of blood and oxygen to the heart.

Valsartan is an ARB that selectively inhibits the binding of angiotensin II to AT1, which is found in many tissues such as vascular smooth muscle and the adrenal glands. This effectively inhibits the AT1 - mediated vasoconstrictive and aldosterone - secreting effects of angiotensin II and results in a decrease in vascular resistance and blood pressure.<smiles>CCCCC(=O)N(Cc1ccc(-c2ccccc2-c2nn[nH]n2)cc1)[C@@H](C(=O)O)C(C)C</smiles>

Figure 1: Showing chemical structure of VLS

\section{Materials and Methods}

\section{Apparatus and chemicals}

A Systronics UV - Visible double beam spectrophotometer 2203 with $1 \mathrm{~cm}$ matched quartz cells was used for all spectral and absorbance measurements. A Systronics digital $\mathrm{pH}$ meter 361 was used for $\mathrm{pH}$ measurements. All the chemicals used were of analytical grade Tablets were purchased from local market. CTC solution prepared by dissolving $7.25 \mathrm{~g}$ of cobalt nitrate and $3.8 \mathrm{gm}$ of ammonium thiocyanate in $100 \mathrm{ml}$, of distilled water, nitrobenzene used as it is. Buffer $\mathrm{P}^{\mathrm{H}} 2.0$ Solution Prepared by mixing $306 \mathrm{ml}$ of trisodium citrate $(0.1 \mathrm{M})$ with $694 \mathrm{ml}$ of $\mathrm{HCl}(0.1 \mathrm{M})$ and the $\mathrm{pH}$ was adjusted to 2.0 .

\section{Standard drug solution}

The stock solution of drug was prepared by dissolving 100 $\mathrm{mg}$ in $100 \mathrm{ml}$ distilled water. A portion of this stock solution was diluted stepwise with the distilled water to obtain the working standard drug solution of concentrations of 100 $\mu \mathrm{g} / \mathrm{ml}$. from the stock solution, a series of standards were freshly prepared during the analysis day.

\section{Preparation of sample solution}

An accurately weighed portion of the powdered tablets equivalent to $100 \mathrm{mg}$ of drug was dissolved in $20 \mathrm{ml}$ of methanol $(\mathrm{MeOH})$, shaken well and filtered. The filtrate was diluted to $100 \mathrm{ml}$ with $\mathrm{MeOH}$ to get $1 \mathrm{mg} / \mathrm{ml}$ solution of drug in formulations. 


\section{Assay}

Aliquots of standard drug solution $(0.5-3.0 \mathrm{ml}, 400 \mu \mathrm{g} / \mathrm{ml})$ were delivered into a series of calibrated tubes. $2.0 \mathrm{ml}$ of buffer ( $\mathrm{pH} 2.0)$ and $5.0 \mathrm{ml}$ of CTC solutions were added and the total volume in each tube was adjusted to $15 \mathrm{ml}$ with distilled water. The solutions in the tubes were transferred to $125 \mathrm{ml}$ separating funnel. To each separating funnel $10 \mathrm{ml}$ of nitrobenzene was added and the contents were shaken for $2 \mathrm{~min}$. The two phases were allowed to separate and the absorbance of the separated nitrobenzene layer was measured after $20 \mathrm{~min}$. at $\lambda \max 605 \mathrm{~nm}$ against a similar reagent blank. The amount of VLS in a sample was obtained from the Beers - Lambert's plot.

\section{Results and Discussion}

In developing this method, a systematic study of the effects of various parameters were undertaken by varying one parameter at a time and controlling all others fixed. The effect of various parameters such as time, temperature, volume and strength of (CTC, Nitrobenzene) reagents, order of addition of reagents on color development and solvent for final dilution of the colored species were studied and the optimum conditions were established. Other water miscible solvents like methanol, ethanol, propan - 2 - ol and acetonitrile were found to provide no additional advantage. The optical characteristics such as Beer's law limit, Sandell's sensitivity, molar absorptivity, percent relative standard deviation (calculated from the six measurements containing 3/4th of the amount of the upper Beer's law limits), Regression characteristics like standard deviation of slope $(\mathrm{Sb})$, standard deviation of intercept (Sa), standard error of estimation (Se) and \% range of error (0.05 and 0.01 confidence limits) were calculated and are shown in Table 1. Commercial formulations containing FFH were successfully analyzed by the proposed method. The values obtained by the proposed and reference method (reported UV method in methanol, $\lambda \max 289 \mathrm{~nm}$ ) for formulations were compared statistically by the $\mathrm{t}$ - and $\mathrm{f}$ - test and found not to differ significantly. As an additional demonstration of accuracy, recovery experiments were performed by adding a fixed amount of the drug to the preanalyzed formulations at three different concentration levels. These results are summarized in Table - 2. The ingredients usually present in formulations of VLS did not interfere with the proposed analytical method.

\section{Chemistry of colored species:}

Cobalt thiocyanate (CTC) [formed from the combination of ammonium thiocyanate and cobalt nitrate] has been proved to be a valuable reagent for the determination of amino compounds. In the present investigation the colored species formed is the co - ordination complex of tertiary amine of VLS (electron donor) and central metal of the cobalt thiocyanate (acceptor) which is extractable into nitrobenzene from aqueous solution.

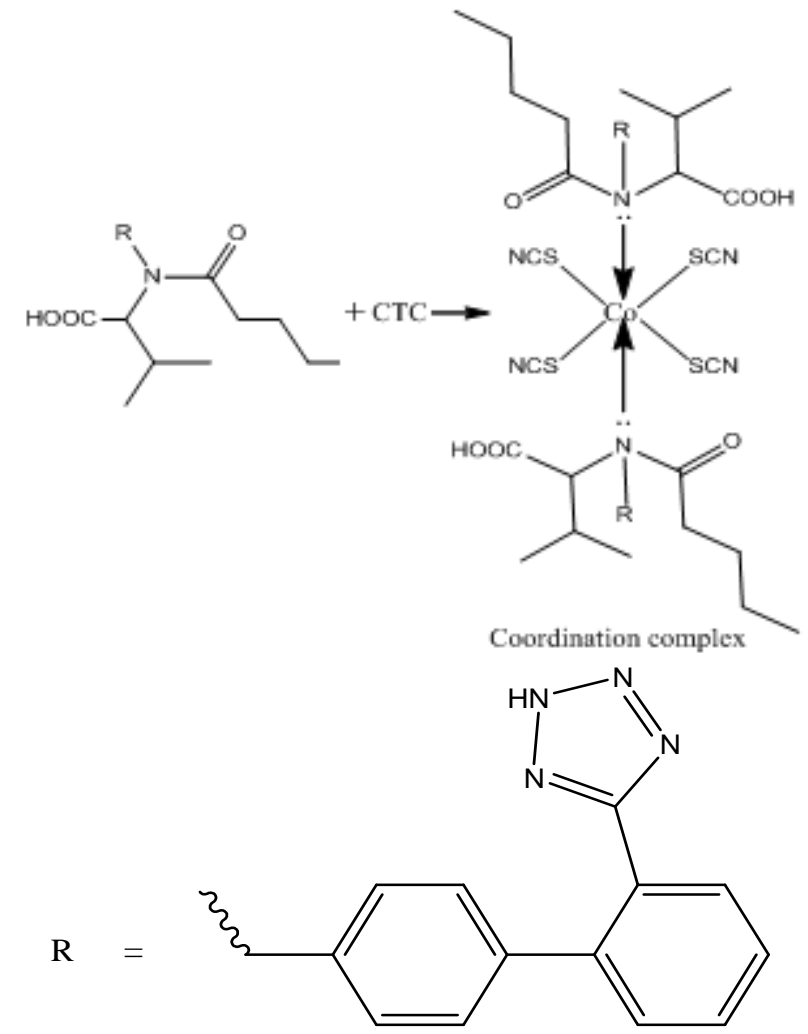

Figure 2: Showing the Scheme

Table 1: Optical characteristics, precision and accuracy of proposed analytical method

\begin{tabular}{|l|c|}
\hline \multicolumn{1}{|c|}{ Parameter } & Values \\
\hline$\lambda_{\max }(\mathrm{nm})$ & 605 \\
\hline Beer's law limits $\left(\mu \mathrm{g} \mathrm{ml}^{-1}\right)$ & $8-48$ \\
\hline Detection limits $\left(\mu \mathrm{g} \mathrm{ml}^{-1}\right)$ & 3.264 \\
\hline Molar absorptivity $\left(1 \mathrm{~mole} \mathrm{~cm}^{-1}\right)$ & $1.407 \times 10^{5}$ \\
\hline Sandell's sensitivity $\left(\mu \mathrm{g} \mathrm{cm}^{-2} / 0.001\right.$ absorbance unit) & 0.00773 \\
\hline Regressionequation $(\mathrm{Y}=\mathrm{a}+\mathrm{bC})$ Slope $(\mathrm{b})$ & 0.013 \\
\hline Standard deviation of slope $\left(\mathrm{S}_{\mathrm{b}}\right)$ & $4.54 \times 10^{-4}$ \\
\hline Intercept $(\mathrm{a})$ & 0.009 \\
\hline Standard deviation of intercept $\left(\mathrm{S}_{\mathrm{a}}\right)$ & $1.414 \times 10^{-2}$ \\
\hline Standard error of estimation $\left(\mathrm{S}_{\mathrm{e}}\right)$ & $1.520 \times 10^{-2}$ \\
\hline Correlation coefficient $\left(\mathrm{r}^{2}\right)$ & 0.995 \\
\hline Relative standard deviation $(\%) *$ & 0.6783 \\
\hline$\%$ Range of error $($ Confidence limits) $* 0.05$ level & 0.7119 \\
\hline 0.01 level & 1.1165 \\
\hline$\%$ Error in bulk samples ** & 0.386 \\
\hline
\end{tabular}

$*$ : Average of six determinations considered $* *$ : Average of three determinations

Table 2: Analysis Valsartan by proposed and reference methods

\begin{tabular}{|l|l|l|l|l|l|l|}
\hline Method & Formulations & Labeled Amount $(\mathrm{mg})$ & Found by Proposed Methods & $\mathbf{t}$ & $\mathbf{f}$ & Recovery by Proposed \\
\hline CTC & Tablet - 1 & 80 & $79.612 \pm 0.364$ & 0.56 & 1.93 & $99.446 \pm 0.263$ \\
\hline
\end{tabular}

Average \pm Standard deviation of six determinations, the $t-$ and $f$ - values refer to comparison of the proposed method with UV reference method. Theoretical values at $95 \%$ confidence limits $\mathrm{t}=2.57$ and $\mathrm{f}=5.05$.

\section{Conclusion}

The reagents utilized in the proposed method are cheap, readily available and the procedure does not involve any critical reaction conditions or tedious sample preparation. The proposed extractive colorimetric method is validated as 
per ICH guide lines and possess reasonable precision, accuracy, simple, sensitive and can be used as alternative method to the reported ones for the routine determination of VLS depending on the need and situation.

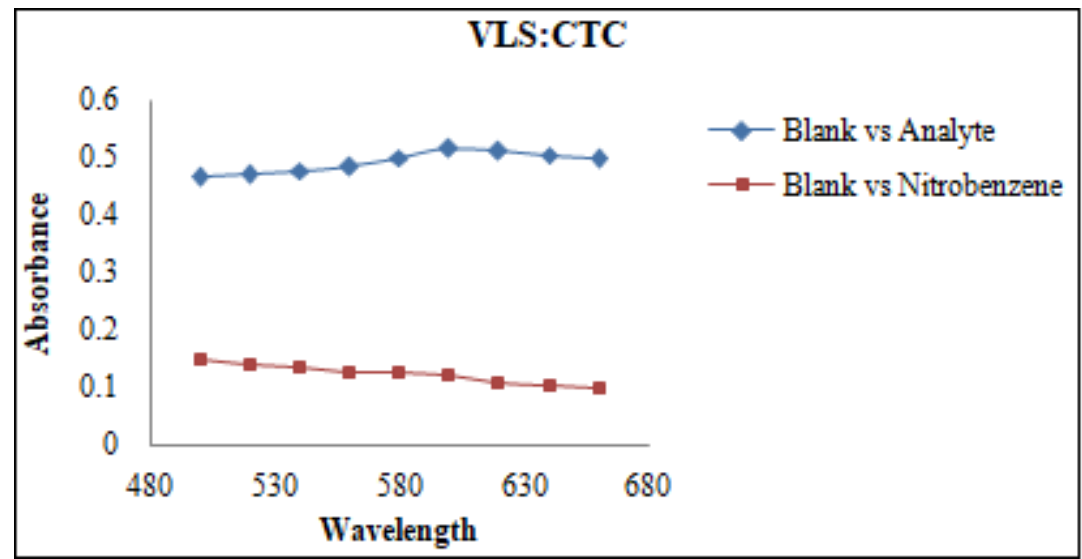

Figure 3: Absorption spectra of VLS - CTC

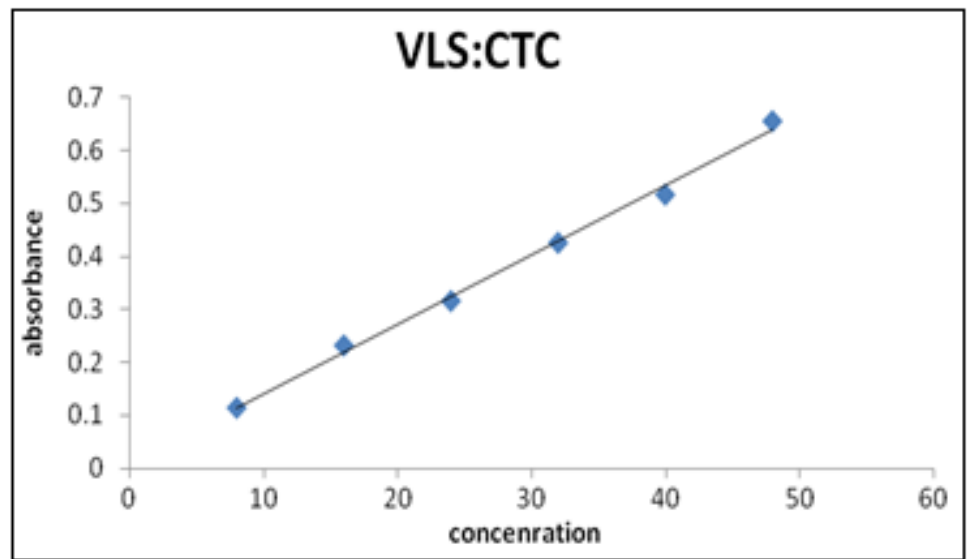

Figure 4: Beer's plot of VLS - CTC

\section{References}

[1] Miller MD, Margot $\mathrm{N}$ and Lu B. Genotypic and Phenotypic predictors of the magnitude of response to TDF in antiretroviral experienced patients. J Infect. Dis.2004; 189 (5): 837 - 849

[2] Gallant JE, Dejesus E and Arribas JR. Tenofovir Disoproxil fumarate, Emtricitabine and Efavirenz Vs Zidovudine, Lamivudine and Efavirenz for HIV. N. Engl. J. Med.2006; 354 (3): 251 - 260

[3] Gilead Sciences Inc. Viread (Tenofovir) product monograph. Foster City CA (2001)

[4] Tracy K, Lane B, Jennifer K, Peter LA, Ray M, Delahunty $\mathrm{T}$ and Courtney VF. Liquid chromatography - tandem mass spectrometric determination of tenofovir - diphosphate in human peripheral blood mononuclear cells. J. Chromatogr. B.2006; 843 (2, 7): $147-156$

[5] Delahunty T, Bushman L and Fletcher CV. Sensitive assay for determining plasma tenofovir concentration by LC/MS/MS. J. Chrom. B. Analyt. Technol. Biomed life Sci.2006; 830 (1): 6 - 12.

[6] Naser LR, Rustin D and Angela DM. Simultaneous quantification of emtricitabine and tenofovir in human plasma using high - performance liquid chromatography after solid phase extraction. J. Chromatogr. B.2005; 822 (1 - 2): 201 - 208.
[7] Sentenac S, Fernandez C, Thrillers A, Lechat P and Aymard G. Sensitive determination of tenofovir in human plasma samples using reversed - phase liquid chromatography. J. Chromtogr. B.2003; 793 (2): 317 324.

[8] Raju NA and Begum S. Simultaneous RP - HPLC method for the estimation of Emtricitabine, Tenofovir and Efavirenz in tablet dosage forms. Research $\mathrm{J}$. Pharm \& Tech.2008; 1 (4): 522 - 525

[9] Rey E, Pons G, Treluyer J and Julien V. Determination of Tenofovir in Human plasma by HPLC with spectroflourimetric detection. J Chrom. B.2003; 785 (2): $377-381$

[10] Joshi M, Nikalje AP, Shahed M, Dehghan M. HPTLC method for the simultaneous estimation of emtricitabine and tenofovir in tablet dosage form. Indian J. Pharm. Sci.2009; 71 (1): 95 - 97

[11] Sparidans RW, Crommentuyn KML, Schellens JHM and Beijnen JH. Liquid chromatographic assay for the antiviral nucleotide analogue tenofovir in plasma using derivatization with chloroacetaldehyde. J. Chrom B.2003; 791 (2): 227 - 233

[12] El - Barkil M, Gagnieu MC and Guitton J. Relevance of a combined UV and single mass spectrometry detection for the determination of tenofovir in human plasma by HPLC in therapeutic drug monitoring. J Chrom. B. Analyt. Technol. Biomed life Sci.2007; 854 (2): $192-197$ 